\title{
Indigenous Australian-Indonesian intermarriage: negotiating citizenship rights in twentieth-century Australia ${ }^{1}$
}

\author{
Julia Martínez
}

This story of Indigenous Australian-Indonesian intermarriage is one that sheds light on the changes to citizenship entitlement in Australia and the struggles of Aboriginal, Torres Strait Islander and Asian peoples to lead their lives free from government intervention. Indonesian-Australian contacts remain relatively unknown in Australian history. Early Macassan relations with the peoples of Northern Australia, brought to light by Campbell Macknight, stands out in Australian history as a significant first contact with Asia. More recently Regina Ganter has continued the Macassan story into the twentieth century exploring encounters with northern communities across Australia. ${ }^{2}$ But the story of wartime disruption faced by the families of Indonesian men and Aboriginal and Torres Strait Islander women and their long wait for citizenship rights has yet to be told.

In Australia, the history of Indonesian migration has tended to be overshadowed by European preoccupations with the larger numbers of Chinese immigrants and, in the context of the pearl-shell industry, with the skill and status of Japanese divers. In the 1981 special edition of Aboriginal History, Athol Chase wrote of encounters with Asians in the Queensland pearl-shell industry describing the influence of Japanese language and culture. ${ }^{3}$ He mentioned the presence of 'Malays' on Thursday Island but gave little sense of the significance of their legacy for the Aboriginal peoples of northern Queensland. It would be almost 20 years before historians would begin to piece together these stories. My aim here is to focus on Indonesians in an effort to shed light on their experiences. This article builds on Regina Ganter's discussion of Indonesian families from Badu and Thursday Islands in the Torres Strait. ${ }^{4}$ The terms Malay, and more specific terms such as Macassan and Koepanger, have been used to refer to people from the Dutch East Indies. ${ }^{5}$ The term Indonesian, which relates to the post-colonial period after 1949, is used here as a general term.

1 Thank you to the anonymous readers for their helpful suggestions. This research was supported under Australian Research Council's Discovery Projects funding scheme (DP0771117).

2 Macknight 1976; Ganter 2006.

3 Chase 1981.

4 Ganter 2006: 193.

5 See Campbell Macknight's discussion of terminology in this volume. 
While the Queensland case study is significant, it should be acknowledged that this story could be told of communities in both Western Australia and the Northern Territory. Western Australia's Kimberley coast was the site of generations of intermarriage between Indonesians and Aboriginal peoples. Sarah $\mathrm{Yu}$ has written of these experiences, critically exposing the stereotypes imposed on Malay-Aboriginal encounters including the notion that Asian fathers did not care about their children. She points to the fact it was the government policy of deportation that forced Malay fathers to leave their children behind. ${ }^{6}$ Christine Choo has explored the restrictions imposed by missionaries in their effort to curtail contact between Aboriginal women and Malay men. ${ }^{7}$ In Darwin, another of the pearling ports, Malay-Aboriginal families such as the Pons and Ah Mats were well-known and respected. Further post-war immigration led to more Indonesians marrying into local communities. ${ }^{8}$

In exploring the lives of just a few Indigenous Australian-Indonesian families, I hope to demonstrate that their experiences, far from being marginal to Australian history, were central to post-war challenges to the White Australia policy. In the context of the immigration policy, marriages between Indigenous Australians and Indonesians highlighted inherent flaws in Australian immigration policy and the fact that citizenship legislation took little account of marriage status. The fact that these marriages also came under the jurisdiction of state-based administrators of Aboriginal affairs added a level of complexity to an already fraught issue of public interference in private lives.

The 2003 publication of Lost in the Whitewash: Aboriginal-Asian Encounters in Australia highlighted the need for Australian history to move beyond the blackwhite binary of the colonisers and the colonised. ${ }^{9}$ Ann McGrath's contribution demonstrated the degree of government control over intermarriage, noting that the Northern Queensland Protector, Walter Roth, was opposed to Aboriginal marriage to 'coloured aliens'. His chief concern was that Chinese men, who had been barred from employing or cohabiting with Aboriginal women under the Aboriginals Protection and Restriction of the Sale of Opium Act 1897, were marrying to get around the Act. By 1901 new regulations forced those wishing to marry to apply to the local police officer, who would then refer the matter to Protector Roth. ${ }^{10}$ Each case was considered individually and in 1901 several Javanese and Malay men were granted permission to marry. McGrath also notes that in 1927 in Queensland four Malays were issued marriage permits. ${ }^{11}$

The level of government control over marriage demonstrates that the White Australia policy was far more than a matter of immigration restriction. It was the basis for internal population control including the criminalisation of miscegenation. In the first two decades after Federation, steps were taken to

6 Yu 1999: 66.

7 Choo 2001.

8 Yu 1999: 66; Choo 2001; Martínez 1999: 49. See also Stephenson 2009.

9 Edwards and Shen 2003: 9.

10 McGrath 2003: 44.

11 McGrath 2003: 45. 
limit the growth of the so-called 'half-caste' Aboriginal population because of fears that population growth would undermine the work of government officials towards achieving a predominantly white population. In Darwin, where the Federal government had authority from 1911, anthropologist Baldwin Spencer advised against allowing intercourse between Aboriginal women and men of other 'races' ${ }^{12}$ He was mostly concerned to prevent Chinese men from having sexual relations with Aboriginal women but the policy was also aimed at white men.

The official stance on miscegenation was stated in section 53 of the Northern Territory Aboriginals Ordinance 1918:

Any person (except an aboriginal or a half-caste not living with his wife) who-

(a) habitually consorts with a female aboriginal or half-caste ; or

(b) keeps a female aboriginal or half-caste as his mistress ; or

(c) unlawfully has carnal knowledge of a female aboriginal or halfcaste,

shall be guilty of an offence. ${ }^{13}$

Men found guilty were liable for up to three months imprisonment. As in Queensland, interracial marriage was only permitted with the permission of the Protector.

Katherine Ellinghaus, in her study of interracial marriage, refers to national policies of 'biological absorption'. ${ }^{14}$ It was not until the 1930s that biological assimilation was considered as an official policy. Dr Cecil Cook, Chief Protector of Aboriginals in the Northern Territory and AO Neville, Chief Protector in Western Australia, advocated the absorption of 'half-castes' into the white population. ${ }^{15}$ Cook's policy was to encourage the 'mating of white male and halfcaste female, thereby gradually eliminating colour' ${ }^{\prime 16}$ This was a controversial plan in the 1930s, not because of humanitarian objections, but because of the lingering belief in white racial purity. But this shift in racial policy made little difference to Asian men. Asian-Aboriginal relations continued to be policed and prevented in the context of immigration concerns, using the excuse that Asian men were a morally degrading influence. ${ }^{17}$ For those few relationships that were permitted, it was on the understanding that minor exceptions would have little impact on broader population goals.

12 'Northern Territory Marriage with Aboriginals', National Archives of Australia [hereafter NAA] A1/1 1912/3519.

13 Ordinance No 9 of 1918, Government Gazette, 26 October 1918.

14 Ellinghaus 2006: 208.

15 Anderson 2002: 246.

16 Cook to Morley, 28 April 1931, NAA A1/1 1936/6595.

17 Martínez 2006: 142. 


\section{Indonesians arrive in Thursday Island}

This account of Indigenous Australian-Indonesian intermarriage begins in the 1870s when pearling stations were established on the islands adjacent to Thursday Island, Kaurareg territory, and thousands of Asian men were brought to work in the pearl-shell industry. ${ }^{18}$ The first Malay divers were introduced shortly after 1874. Some men, from the western regions of the Dutch East Indies, were brought to Australia via Singapore, recruited by 'coolie' brokers and shipped under three-year contracts of indenture. Others, from the eastern islands of the Dutch East Indies, were recruited from Kupang in West Timor, Ambon, and Dobo in the Aru Islands. They came from islands in Timor and Maluku, including Babar, Roti, Alor and Sawu Islands. The cultural heritage of these islands, with animist traditions and Christian influences, had more in common with the Torres Strait Islands than with the Javanese culture most often associated with Indonesia. There were some obvious differences however. Jeremy Beckett has argued that the Asian men had a marked impact on Torres Strait society, as they 'introduced marriage payments in the form of cash and manufactured goods' which in turn prompted Torres Strait Islander men to offer matching payment for wives. ${ }^{19}$

The first census taken at Thursday Island in 1885 indicated a resident population of 139 Europeans, 77 Malays, 49 Filipinos, 20 Sri Lankans, 16 Aboriginal people, and a handful of Chinese, Japanese and Arabs. In that same year there were 257 Malays engaged in the marine industry and this peaked at 270 in $1886 .{ }^{20}$ Apart from Malays, the pearling masters employed Pacific Islanders and 'Manilamen'. ${ }^{21}$ In 1896 the population was 1354, including 626 Europeans, 233 Japanese, 119 Filipinos, 115 Malays, and Chinese, Pacific Islanders, Aboriginal Australians, Cingalese, and Javanese. There was a small second generation of Malays with the census recording three Malay women and 14 children. The number of Malays on fishing vessels remained steady with 270 Malays employed.22 By 1902 there was a reduction in the number of Malays with the pearl-shell crews including 172 Malays compared with 397 Pacific Islanders and 246 Torres Strait Islanders. ${ }^{23}$

After 1901 the pearl-shell industry was granted an exemption from the Immigration Restriction Act 1901 and permitted to import Asian workers on yearly Certificates of Exemption. This exemption came under question in the 1910s and was only made official after a Royal Commission. ${ }^{24}$ The decision to allow Asian indenture was made on the proviso that Asian indents would not remain in Australia permanently and that they would have limited contact with Australian society. Intermarriage defied both those objectives.

18 Shnukal and Ramsay 2004: 35.

19 Beckett 1977: 85.

20 Shnukal and Ramsay 2004: 37-38.

21 Beckett 1977: 82.

22 Brisbane Courier, 24 November 1897: 5.

23 Dashwood 1902: 4

24 Ganter 1994: 112. 
The Commonwealth Naturalization Act 1903 replaced the Queensland Aliens Act 1867. Under the Queensland Act, Asians had been able to apply for naturalisation provided they were married and had lived in Queensland for three years. ${ }^{25}$ The new Commonwealth Act denied naturalisation to any 'aboriginal native of Asia' ${ }^{26}$ Marriage, therefore, was no longer relevant to naturalisation.

While marriage may not have helped to secure permanent residence for Indonesian husbands, it did afford their wives a greater degree of freedom. If Torres Strait Islander women had been subject to the letter of the law, then by virtue of the 1903 Naturalization Act, which specified that a married woman took on her husband's nationality, then these women would have become citizens of the Dutch East Indies. But full citizenship was available to neither party as colonised subjects. Even so, these marriages did lead to the wives becoming exempt from the controls placed on Aboriginal and Torres Strait Islanders under the Act. This, however, remained a legal 'grey area' throughout Australia. It apparently did not apply in the Northern Territory Aboriginals Ordinance 1918, in which 'Aboriginal' included 'a female half-caste not legally married to a person who is substantially of European origin or descent and living with her husband'. As in Thursday Island, however, in practice married women in Darwin were more likely to be permitted to live independently.

In 1904 Torres Strait Islanders were classified as 'Aboriginal' and the children of Asians and Torres Strait Islanders were classed as 'half-caste' and subject to the Act if they lived with or 'habitually associated with' Aborigines and Torres Strait Islanders. ${ }^{27}$ In order to avoid these restrictions, Asian-Torres Strait Islander families moved to Thursday Island. Here they were apparently disconnected from their Aboriginal families, who were not permitted to move to Thursday Island under legislation aimed at segregating Asians from Aboriginal people. ${ }^{28}$ One such example was Ahwang Dai, a Dayak, who came to the Torres Strait in the 1880s from Singapore and in 1891 married Annie from Badu Island and had 11 children. ${ }^{29}$

As Asian men and their families congregated on Thursday Island, the next generation of Asian-Aboriginal children were more likely to marry newly arrived Malays. Those children deemed to be 'half-caste' and under the age of 21 were still subject to the rule of the Protector. In 1914 the Protector of Aborigines, William Lee-Bryce denied Atima, the daughter of Ahwang Dai, permission to marry a Malay man. Instead, Atima was married informally in 'Malay fashion'. ${ }^{30}$ In another case, Cissie Malay, who was 'designated as a half-caste Aboriginal woman and under the age of $21^{\prime}$, was also forbidden to marry when Drummond Sarawak applied for permission in $1916 .{ }^{31}$ Despite this, the couple were married

25 Shnukal and Ramsay 2004: 43.

26 'An Act relating to Naturalization', No 11 of 1903, Commonwealth Parliamentary Papers: 91.

27 Shnukal and Ramsay 2004: 44.

28 Shnukal and Ramsay 2004: 44.

29 Ganter 2006: 83

30 Ganter 2006: 83-84.

31 Faulkner 2007: 6-7. 
unofficially and their son Ali Drummond was born in 1917. Cissie Malay was the daughter of a Yadhaigana woman, Nara Para from Red Island, and a Javanese man known as Jimmy Malay. ${ }^{32}$

In some cases marriages were permitted. Bora Bin Juda, who was born in Macassar in 1895, came to work on Thursday Island aged 19..$^{33}$ On 29 December 1922, he married Mareja Doolah, who was born on Badu Island in 1902. In a letter to the Sub-Collector of Customs on Thursday Island, JG McLaren, Secretary of the Department of Home and Territories wrote that the Protector of Aboriginals had recommended that 'no further objection need be raised to the marriage in this case' ${ }^{34}$ He agreed to allow Bora Bin Juda to remain in Australia and to re-engage as an indent for further service 'subject to good behaviour'. The exception was made because Mareja Doolah was officially categorised as a 'three-quarter caste Malay'. But McLaren wrote that he would be glad if the Sub-Collector would inform employers that:

the marriage of indents to local women is to be discouraged and that serious consideration will be given to the question of refusing to allow the re-engagement of any indent who in future marries locally. ${ }^{35}$

That is to say that after the marriage had taken place the men would be deported. An investigation showed that there were six other Malay indents married to or living with 'half-caste' Aboriginal women, namely Bagu Bin Amat (with two children), Olie Daybees (Willen Dewis), (two children), Hadji Salem (two children), Doola, (one child), Sayed Bada (five children), Tommi Loban (two children), and Subden Bin Osane (two children). ${ }^{36}$

It would appear that at this time the government's first priority was to prevent Indonesians from gaining permanent residence and that the prospect of a child being left without a father was justified on these grounds. McLaren wrote:

it is realised that if an indent gets a lubra into trouble, it is reasonable to expect him to recognise his responsibilities in the matter; but if such a person were permitted to marry at Thursday Island and thus be practically assured of permanent residence, there would appear to be some danger that other indents might follow his example for the purpose of securing like concessions, and the question arises as to whether it would not be preferable on the whole to prevent marriage in such cases and to require the indent to leave the Commonwealth as soon as his term of engagement expires. ${ }^{37}$

32 Faulkner 2007: 5-12.

33 Application for Registration, 17 February 1940, NAA J25 1957/4689.

34 McLaren to Sub-Collector, 10 November 1922, NAA A1 1922/19013.

35 McLaren to Sub-Collector, 10 November 1922, NAA A1 1922/19013.

36 Customs and Excise Memo, 17 October 1922, NAA A1 1922/19013.

37 McLaren to Sub-Collector, 15 September 1922, NAA A1 1922/19013. 
Given that marriage no longer served to make Malays eligible for naturalisation, it was a curious reading of the law, to suggest that marriage to an Aboriginal Australian would 'practically' assure them permanent residence.

In another case, in Western Australia, there was no such assumption. In 1936, after a Malay indent married a 'half-caste' woman, the Broome Pearling Inspector stated that despite the marriage he would have to leave the country 'when he ceases to be employed on pearling vessels' ${ }^{38}$ Despite this, the man was permitted to remain in Australia in yet another example of officials bending the rules.

In 1939 with the review of the Protection Act by Chief Protector Bleakley two separate Acts were promulgated in Queensland: the Aborigines Preservation and Protection Act 1939, and the Torres Strait Islanders Act 1939. While Torres Strait Islanders were described as a distinctive group, and believed to be living in a 'more developed' way than mainland Aboriginal people, they were still subject to similar government surveillance and control of work and wages. ${ }^{39}$ Torres Strait Islander women who had married Malay men and were living outside the Protection Act on Thursday Island were relatively free from this control, but that was to change during the Second World War.

\section{War-time evacuation}

On 24 January 1942, fearing that Japan was about to attack Australia, the government gave the order to evacuate Thursday Island. ${ }^{40}$ The evacuation ships made their way south to Cairns and the Orminston disembarked a number of Aboriginal-Indonesian families. Afterwards there were claims of an adverse public reaction to the new 'coloured' arrivals. The Army and the Deputy Director of Native Affairs, Cornelius O'Leary, decided to send the next shipment of approximately 200 Thursday Islanders on the Katoora and the Britha to the Cherbourg Aboriginal Settlement located 272 kilometres north-west of Brisbane. Once there, the men were signed up to work in a range of jobs including sugarcane-cutting, cotton-picking and cattle work.

While the Malay men were sent out to work, the women and children mostly remained in Cherbourg. They found themselves alone, cold, and unable to leave because they were now being treated as 'wards' under the Act. From 1911 to 1940 nearly 6000 mainland Aboriginal people had been removed to settlements such as Cherbourg as part of an attempt to segregate the Aboriginal population. Their first experience of this regime was shocking to Thursday Island families. ${ }^{41}$

38 Pearling Inspector to Chief Pearling Inspector, 2 April 1936, State Records of Western Australia (SROWA) 477 245/1936.

39 Ganter and Kidd 1993: 553.

40 Osborne 1997: 16.

41 Osborne 1997: 31-35. 
In June 1942 Willem Dewis (known as Olie Daybees), an Indonesian from Thursday Island, went to Cherbourg to try to get the Indonesians released with the idea that they could move to Brisbane. Dewis was born in Tepa on Babar Island in Maluku in 1893. His wife, Noressa, was born on Badu Island. They had eight children, the youngest, Josephine being born in 1945. O'Leary supported racial segregation to an extent that was unfamiliar to Thursday Islanders and condemned Dewis' attempt to 'get every Malay to Brisbane' where, O'Leary argued, 'they would become a menace to health and objectionable residents of any suburb' ${ }^{42}$ He claimed that all the Indonesians were employed in Cherbourg whereas in Brisbane they would be unemployed.

Dewis had already contacted Police Sergeant Holly at Thursday Island in an attempt to gain his help. Living in Red Hill, Brisbane, Dewis wrote that they had been forced to go to Cherbourg which he described as 'not a nice place' and 'only good for the aboriginal not for us because you know for yourself Sir how we lived up T.I.' He complained about the quality of the food they were given, being fed with bread and jam but no butter. They were given meat every second day but no vegetables. He said he had complained to Mr O'Leary but to no avail. Dewis wrote that he did not wish the Department of Native Affairs to be in charge of them. Demonstrating the extent of their lack of personal freedom, he wrote that the families at Cherbourg had been split up with husbands and wives sleeping apart in dormitories, and boys and girls also sleeping apart. He wrote that they 'are like prisoners because they are not allowed to sit with their family and have their meals' ${ }^{43}$

O'Leary was adamant that the Thursday Island evacuees were not to leave Cherbourg. He wrote to the superintendent of Cherbourg stating that: 'Under no circumstances must any evacuee leave your Settlement without my permission'. His concern was that Palos Annidlah, stepfather of Sammy Lewin, had apparently been given permission to leave by the superintendent. Sammy Lewin had come to Brisbane and had been admitted to Wattlebrae Hospital suffering from typhoid fever which they presumed he had contracted at Cherbourg Settlement. The superintendent was ordered to arrange for inoculations immediately. ${ }^{44}$ Given that typhoid fever is usually contracted from contaminated food or water, this points to the dire state of hygiene in the Cherbourg Settlement.

Bora Bin Juda was living at the Cherbourg with his wife Mareja and their four children. He worked there until he broke his arm when breaking in a horse. In January 1943 Bin Juda left to look for work but his wife remained at Cherbourg. He was employed in a range of short-term jobs: as a builder's labourer for $£ 4$ per week, as a sugarcane cutter; and then in the Farleigh Sugar Mill for $£ 5$ per week. Later in 1943 Bin Juda went to Red Hill, Brisbane and was employed by the Civil

42 Deputy Director of Native Affairs, 24 June 1942, Queensland State Archives [hereafter QSA] $\mathrm{IF} / 44$.

43 Dewis to Sergeant Holly, 19 May 1942, QSA IF/ 44.

44 Deputy Director of Native Affairs, 22 May 1942, QSA IF/ 44. 
Construction Corps on the New Dock at Bulimba for $£ 15$ per fortnight. He paid $£ 1$ per week to rent a house that he shared with his son Saul Juda who was then 15 years old. ${ }^{45}$

Whilst the men were able to leave Cherbourg to seek employment it was another matter to get their wives and children out. There was some suggestion that the government was paying for their accommodation but according to the Director of Native Affairs the fee for accommodation at Cherbourg was 1 shilling per person per day, payable by the husband. In the period from March to October 1942 the accommodation of one wife and six children was calculated as $£ 64 / 1 /$ or several months wages. The men were sent letters demanding payment before their wives and children could be released. A poignant record of this troubled time was a simple telegram from Dorsena Bin Garape to her husband Assan Bin Garape stating: 'Can't leave here unless you pay settlement, love Dos'. In December 1942, Bin Garape, who was employed at the Mackay aerodrome, sent money for fares to Mackay and agreed to pay the rest of the money in instalments. Dorsena was given approval to join her husband in Mackay on 14 December $1942 .{ }^{46}$

The war years must have been extremely difficult for those who had large families, even after they were permitted to leave Cherbourg. Hassan Bin Awel, who was born in Amboina, Maluku in 1891, was married to Saia Ah Wang, born on Badu Island in 1909. They were married in 1926 and had seven children. Before the war Hassan was working on-shore in connection with the pearling industry. During the war years, Hassan was moved around Queensland. He shifted from Mackay to Chermside in February 1943 to work in the Civil Construction Corps camp and after one month was transferred to Tamborine for another five months. After that he went on to Meeandah for a few months and then to the Banyo Civil Construction Corps to work for the Main Roads Commission. In January 1944 he was living in Kelvin Grove with his wife and children. By the end of the year he had moved to live in Paddington, though he was still employed by the Banyo Civil Construction Corps. The government files that so carefully track his whereabouts have very little to say about the difficulties that his wife and children must have experienced during these years of constant moving. Two of their children were born during these years so they had small babies to look after as well. In February1947 Hassan moved again to live in Red Hill where he was employed by the City Council. The government then requested that he return to Thursday Island where he worked until his retirement in $1956 .{ }^{47}$ His story is typical for the Indonesians who were evacuated from Thursday Island.

45 Reports by Constable 3142 Red Hill Station, 29 July 1943; Constable 3295, Rosalie Station, Brisbane, 26 July 1943; Constable 3063 Farleigh Station 14 August 1943, NAA J25 1957/4689.

46 'Evacuation Coloured People other than Islanders and Aboriginals', QSA IF/ 44.

47 Nulty, 20 November 1959, NAA J25 1957/12548. 


\section{Post-war Thursday Island - towards naturalisation}

Following the end of the war, the government was eager to reestablish the pearlshell industry in Queensland and most concerned that there were Asian indents moving around freely in Australia against the terms of their contracts. The Department of Immigration quickly located the men and demanded that they return to work in the pearling industry or face immediate repatriation. For those who were married to Torres Strait Islander women there was little choice. They were forced to return to Thursday Island. A list of pearling indents employed on Thursday Island during 1951 showed 22 Indonesians identified by their region of birth and these men had some 50 dependents. ${ }^{48}$ The list included ten men from Timor who had arrived in Australia between 1908 and 1934; four men from Makassar, Celebes (Sulawesi) who had arrived between 1911 and 1936; six men from Ambon, arriving between 1914 and 1944; and three others.

Having lived in Cairns and Brisbane during the war years, it was difficult for many of the families to adapt to life back on Thursday Island. In 1950 a letter was sent to Senator Courtice on behalf of $\mathrm{H}$ Joseph, Secretary of the Indonesian Social Club protesting that they had been refused permission to visit Cairns with their children for a holiday. He said that they had been on Thursday Island from 14 to 34 years and that they were not naturalised 'although a considerable amount of money has been spent on legal costs in order to achieve naturalisation' ${ }^{49}$ This was the first suggestion that the pearl-shell workers were seeking naturalisation as a means to avoid deportation.

Historian Sean Brawley has explored a separate naturalisation case, which appeared before the High Court in 1949. Indonesian woman Annie Jacob came to Australia as part of the wartime evacuations from the Dutch East Indies with her husband Samuel Jacob and their children. Her husband died in 1944 and later Annie married white Australian John O'Keefe. Despite their marriage, the Australian government was not prepared to grant her permanent residency. Instead she was granted a temporary Certificate of Exemption from the Immigration Restriction Act 1901-1948. After Arthur Calwell tried to deport Annie the case went to court and the High Court determined in 1949 that she was not a prohibited immigrant on the basis of a technicality - the authorities had failed to administer the Dictation Test. ${ }^{50}$ This case demonstrated beyond doubt that marriage to an Australia at this time did not help those seeking to circumvent the White Australia policy.

The Thursday Island cases were different as these men were long-term temporary residents with Australian-born children, but even these factors were not sufficient in making a case for citizenship. Even so, these factors did sway

48 P Kersley to Commonwealth Migration Officer, NAA J25 1958/850.

49 Collins to Courtice, 26 March 1950, NAA J25 1958/850.

50 Brawley 2006: 4-9. 
the local officials. In June 1950 CW Kirk, Sub-Collector of Customs, who had been in contact with Joseph, wrote in support of their request to go on holidays to the mainland, stating:

I might point out these people all have pretty large families all born on Thursday Is, they had sons overseas on active service in World War 2, and themselves worked on Allied small ships or on defence on the Island. The visits to the mainland for holiday purposes is requested that all should be permitted to go at different times, and it was also suggested at the meeting that the person going on a months holiday with his family should put up a bond. The attached list shows 23 Men and 16 Wives, including one De-facto, the number of Children would average five per family. ${ }^{51}$

The fact that Indonesians were denied freedom of movement within Australia reached the new Indonesian government. Indonesian independence in 1949 brought with it a review by the Indonesian government of colonial labour practices, including conditions in Australia's pearl-shell industry. By March 1952, the Indonesian government was considering banning Indonesian pearling indents from working in Australia. ${ }^{52}$ In 1955, after failing to agree with the Australian government over rights of permanent settlement for Indonesian nationals, the Indonesian government banned further indentured immigration. ${ }^{53}$

While the Indonesians on Thursday Island were lobbying against the restrictions imposed on them by their status as indentured workers, in Canberra a broader debate was taking place over the administration of the White Australia policy. It is not clear to what extent the protests from Indonesians and their supporters influenced government policy. More likely, it was the case of the Japanese wives of returned soldiers that provided the initial catalyst for change. Mrs Cherry Parker, the Japanese wife of Gordon Parker, a white Australian man who had served with the British Commonwealth Occupation Force in Japan, was the first Japanese 'war bride' to be permitted to enter Australia in 1952. Her story, which was splashed across the newspapers of the time, prompted a rethink of the stringent restrictions of the White Australia policy. The media emphasised the romance of their love story and made much of her personal beauty. ${ }^{54}$ The front page of the Argus carried a photograph of their two young daughters and their Australian grandmother with the caption: 'The happiest grandmother in Melbourne'.$^{55}$ As Keiko Tamura observed: 'Their experience presented a case in which faithful love could conquer all barriers: racial, cultural, linguistic and of international relations' ${ }^{\prime}{ }^{56}$

51 Kirk, 19 June 1950, NAA J25 1958/850.

52 Australian Embassy, Djakarta, to DEA, 15 March 1952, NAA A1838/2 1531/ 49.

53 Martínez 2005: 137.

54 Tamura 2001: 249.

55 Argus, 11 July 1952: 1.

56 Tamura 2001: 250. 
The Commonwealth Immigration Advisory Council was asked to review the policy regarding non-Europeans in Australia and in 1954 the council voted to grant Australian citizenship 'to Asians who have permission to remain in Australia without any restrictions under the Immigration Act' ${ }^{57}$ A commitment was made to grant permanent residence to Asians with professional qualifications or distinguished in government or humanitarian service, but that admission of 'lower class' Asians should be prevented. When Harold Holt, Minister for Immigration, presented his recommendations to cabinet in July 1956 they included an additional proposal to adopt 'a more "liberal attitude" towards non-Europeans already in Australia who had breached their entry conditions, especially in relation to restrictions on their occupation' ${ }^{58}$ This recommendation was intended to help those pearling indents who were no longer working in the pearl-shell industry but might otherwise have been dismissed as 'lower class'.

The shift away from the pearl-shell industry was an important step towards achieving naturalisation. Once the Indonesian men were free from the restrictions placed on indents, they could qualify for naturalisation as permanent residents 'not under immigration restrictions'. Non-Europeans seeking naturalisation were required to have been resident in Australia for 15 years (as opposed to five years for Europeans) but this was a minor matter given that most of the pearling indents had been resident long before 1941.

The case of Cherry Parker inspired another important change, which was the 1956 decision to grant naturalisation to the Asian spouses of Australian citizens. She was naturalised in January 1957..$^{59}$ The term 'spouse of an Australian citizen' was soon applied to Indonesian men married to Aboriginal women. Since the passing of the 1948 Nationality and Citizenship Act, Aboriginal peoples had been formally Australian citizens, though this Act did not confer citizenship rights. ${ }^{60}$ For example, Esek Anaktotote, who was born in Tepa on Babar Island in 1910, arrived in Thursday Island in 1926. In 1946 whilst living in Brisbane, Anaktotote married Possa nee Usope, widow of Paolos Annidlah. She was born on Badu Island in 1906. Possa had four children from her previous marriage to Timorese pearling indent Henry Lewin who had died around $1935 .{ }^{61}$ Despite his marriage, in January 1948 the Department of Immigration decreed that if Anaktotote was not prepared to return to work in the pearling industry as an indentured labourer then he would be given one month's notice to leave the country. The Wanetta Pearling Company had offered to sign him on but as they had no pearling boats operating that year the government was not satisfied with this arrangement. ${ }^{62}$ In 1957 his status was changed from 'pearling indent' to 'spouse of an Australian Citizen'. The Sub-Collector of Customs, HJ McMahon, reported in 1957 that he:

57 Tavan 2005: 90.

58 Cited in Tavan 2005: 94.

59 Tavan 2005: 95-98.

60 Chesterman and Galligan 1997: 156.

61 Esek Anaktotote, NAA J25 957/3859.

62 Kersley to Sub-Collector, 7 January 1948, NAA J25 957/3859. 
supports his wife, working on the waterfront as a casual labourer, when available. He receives very good pay. He own and works a small vegetable farm on one of the neighbouring Islands. ${ }^{63}$

At a time when the category of 'spouse of an Australian Citizen' could apply equally to a husband as to a wife, there was still the notion that his financial support for his wife was a necessary factor in his qualifying for this category.

The most pertinent change for Indonesian indents who were officially in Australia as temporary immigrants was the June 1957 recommendation to extend permanent residence and citizenship rights to all non-Europeans who had lived in Australia for 15 years but were still classed as temporary residents. ${ }^{64}$ The Minister for Immigration, Athol Townley, formalised further conditions, that they were 'of good character; had not wilfully disregarded the conditions of their admission; had an adequate knowledge of English; and had taken part in normal Australian life' ${ }^{65}$

Having lived under the shadow of the White Australia policy the indentured workers were finally offered the possibility of naturalisation, providing they passed English language tests and demonstrated involvement in so-called 'normal Australian life'.66 In 195819 Indonesian nationals were granted Australian citizenship and over the next eight years a total of 142 Indonesians were naturalised. ${ }^{67}$ Bora Bin Juda, for example, returned to Thursday Island in 1947 and engaged in pearling until his advanced years forced him to retire from the industry. In 1952 he was employed casually on the wharf. ${ }^{68}$ In 1958 he applied to become an Australian citizen and was naturalised on 11 August 1960. ${ }^{69}$

While the new changes to the naturalisation legislation seemed to suggest that all the Indonesians would now be able to qualify for citizenship, there was still some degree of reluctance on the part of the administrators that suggested disapproval of intermarriage still existed. The application for naturalisation of Albert Herwawa in 1961 was one such case. Herwawa was born in Timor in 1906 and came to Australia in 1926. He returned to Thursday Island after the Second World War and married Ruth Ketchell. Following his application for naturalisation in 1961, the Sub-Collector of Customs sent the Immigration Department a favourable report. He noted that Herwawa had engaged in pearling part-time until 1956 and had worked as a casual wharf labourer since 1948. He was found to qualify for the criteria of mixing with Australians given that as a wharf labourer 'he constantly mixes with Australian workers' and the Sub-Collector noted that his

63 Report, 22 July 1957, NAA J25 957/3859.

64 Tavan 2005: 99.

65 Tavan 2005: 102.

66 Markus 1994: 171.

67 Markus 1994: 172.

68 Nulty to Secretary, 20 November 1959, NAA J25 1957/4689; Draney, 10 December 1952, NAA J25 1958/2442.

69 Bruce to Nulty, 4 September 1957, NAA J25 1957/ 4689. 
home, which was very tidy, was amongst Australians, and that he was able to converse freely in English. He also mentioned that Herwawa was a member of the Malay Club and that his main hobby was fishing. ${ }^{70}$

A second report, however, was sent from the Thursday Island Police Station stating that Herwawa had married a Thursday Island woman, Ruth Ketchell, 'who is many years younger than he' ${ }^{71}$ This police report prompted the Commonwealth Migration Officer, TM Nulty, to write to the Director of Native Affairs seeking his view as to whether or not Herwawa should be granted citizenship. Nulty wrote:

Asian pearling operatives, or former operatives, are only normally eligible to apply for citizenship by virtue of their marriage to Australian citizens but this in itself does not entitle them to naturalization, and each case is considered individually. As the majority of these pearlers ... qualify to apply for naturalization only by reason of their marriage to native women, it is considered desirable to obtain the views of your Department on their suitability to acquire citizenship of this country before proceeding with the grant of naturalization to them. ${ }^{72}$

This request for the permission of the Director of Native Affairs reveals the persistence of the 'Protector' mentality. The Director simply pointed out that the Sub-Collector was responsible for these reports and made no further comment and Herwawa was granted citizenship in 1962.

The process of gaining naturalisation was not merely about freedom of employment or movement. It also conferred a greater financial security for these men as they retired after many long years of working for the benefit of the Australian economy. The story of Karel Kaprisi born on Babar Island in 1907 demonstrates this. He came to Thursday Island in 1926 and married Sophia Takai, a local Thursday Island widow, in 1948. Sophia was of Malay descent and during her stay in Cherbourg she was already widowed with three Malay-Japanese children. She and Karel had four children together and when she died it was left to Karel to care for the large family. In 1955, with diver's paralysis leaving him crippled with arthritis, he was receiving workers' compensation. In 1960, just months before his naturalisation, he received a letter from the Department of Social Services advising him that his benefits were liable to be terminated as he was not an Australian citizen. DA Radke, the Sub-Collector of Customs on Thursday Island, wrote to explain to the Commonwealth Migration Officer in April 1960 advising him that Karel was distressed because he was supporting a family. Thus Karel's naturalisation in August 1960 was a timely intervention and offered the prospect of a more secure financial future. ${ }^{73}$

70 Radke, 10 April 1961, NAA J25 1959/641.

71 Cavanagh, Senior Sergeant, 1 June 1961, NAA J25 1959/641.

72 Nulty to Director of Native Affairs, 27 June 1961, NAA J25 1959/641.

73 Karel Kaprisi, NAA J25 1959/156. 
For some the 1960 naturalisation ceremony came too late. Bagu Bin Amat, who was born in Pontianak, Borneo in 1891, was married to Raima Ah Wang, a Badu Island woman. Together they had six children. The government finally approved his naturalisation application on 27 January 1959 but sadly Bagu Bin Amat died on 11 February 1960 before he could take up Australian citizenship. ${ }^{74}$

During the large naturalisation ceremony held in 1960 on Thursday Island nine Indonesians, former pearling indents, were naturalised. The town clerk reported that some 250 people attended the ceremony and the speakers were WJ Fulton, MHR, HA Adair MLA, and T Gilmore, MLA, who had a special message of congratulations from Dr Noble, the Minister for Health and Home Affairs. ${ }^{75}$ With the Malay men confirmed as Australian citizens they were now entitled to vote in Australian elections. Ironically, their wives, the Australian citizens who helped the men to qualify for citizenship, were, as Torres Strait Islanders, not officially granted the right to vote under Queensland law until 1965 with the passing of the Election Amendment Act 1965.

With no new Indonesian immigration after the 1950s there was a gradual decline in the memory of Indonesian cultural heritage as the next generation tended to identify themselves as Torres Strait Islanders. ${ }^{76}$ Samantha Faulkner wrote about her grandfather Ali Drummond acknowledging his Malay heritage, but also emphasising his current identification as a Torres Strait Islander, writing:

Today, Ali is a respected elder and recognised across Australia. He's a Cultural Ambassador for Thursday Island and the Torres Strait, educating non-Aboriginal and Torres Strait Islander peoples about Aboriginal and Torres Strait Islander culture, which assists greatly in the role of reconciliation. ${ }^{77}$

The stories of Indigenous Australian-Indonesian marriages are important because they enable us to remember and celebrate the endurance of families who survived the dual burdens of immigration restrictions and the so-called protection of the various Aboriginal and Torres Strait Islander acts. In the years since these men gained citizenship, there has been remarkably little recognition of their special place in Australian history. Theirs is a story of patience and persistence in remaining in Australia as temporary residents for some 50 years, hanging on by the tenuous threads of yearly Certificates of Exemption.

As a study of Australian citizenship and marriage law, this article has only touched on some of complex problems posed by this grey area of the law, and the often incompatible regulations imposed by the separate state and federal systems. More work is needed to understand the diversity of the state systems and more importantly the gaps between the letter of the law and its application.

74 Nulty to Adair, 13 July 1960, NAA J25 1958/3085.

75 Allen to Commonwealth Migration Officer, 18 August 1960, NAA J25 1959/1420.

76 Shnukal and Ramsay 2004: 46.

77 Faulkner 2007: 81-82. 
The history of Indigenous Australian-Indonesian intermarriage provides a new, personal dimension to Australia's historical relations with Indonesia. While the histories of early Macassans have given us a sense of Indonesians as temporary visitors who remained outsiders, here, we see Indonesians in quite a different light, as settlers rather than sojourners and with close continuous ties to Aboriginal and Torres Straits peoples and with experiences of Australia that went far beyond their anticipated segregated role in the pearl-shell industry.

\section{References}

\section{Primary sources}

'An Act relating to Naturalization', No. 11 of 1903, Commonwealth Parliamentary Papers: 91.

\section{National Archives of Australia (NAA)}

Association for Protection of Native Races - Aboriginal Matters File No. 1, A1/1 1936/6595, 46104, NAA, Canberra.

Bagu Bin Amat CEDT (Certificate for Exemption from Dictation Test), J25 1958/3085, 967426, NAA, Brisbane.

Barabin, Juda (Pearling Indent) Marriage to Aboriginal woman, A1 1922/19013, 42588, NAA, Canberra.

Bora Bin Juda, J25 1957/4689, 1644216, NAA, Brisbane.

Doraho, Salen Bin, J25 1958/2442, 1657702, NAA, Brisbane.

Esek, Anaktotote, J25 1957/3859, 1642452, NAA, Brisbane.

Hassan Bin Awel, J25 1957/12548, 1653523, NAA, Brisbane.

Herwawa, Albert, J25 1959/641, 1658198, NAA, Brisbane.

Immigration - Admission of Asiatics and others for pearling, A1838/2 1531/49, 551745, NAA, Canberra.

Karpisi Karel, NAA J25 1959/156, 1050504, NAA, Brisbane.

Northern Territory Marriage with Aboriginals, A1/1 1912/3519, 12704, NAA, Canberra.

Pearling, Indentured Labour Admission of Policy, J25 1958/850, 1541063, NAA, Brisbane. 
Titisay, Henry, J25 1959/1420, 1656560, NAA, Brisbane.

Queensland State Archives (QSA)

Evacuation Coloured People other than Islanders and Aboriginals, IF/44, QSA, Brisbane.

State Records Office of Western Australia (SROWA)

Pearling - Enquiry by the Chief Protector of Aborigines re indentured asiatics in Broome, 1936/0245, no 477, SROWA, Perth.

\section{Secondary sources}

Anderson, Warwick 2002, The Cultivation of Whiteness, Melbourne University Press, Carlton.

Beckett, Jeremy 1977, 'The Torres Strait Islanders and the pearling industry: a case of internal colonialism', Aboriginal History 1(1): 77-104.

Brawley, Sean 2006, 'Mrs O'Keefe and the battle for White Australia', Public lecture for the National Archives of Australia, presented in Canberra, 1 June 2006.

Chase, Athol 1981, 'All kind of nation: Aborigines and Asians in the Cape York peninsula', Aboriginal History 5: 7-20.

Chesterman, John and Brian Galligan 1997, Citizens Without Rights, Aborigines and Australian Citizenship, Cambridge University Press, Cambridge.

Choo, Christine 2001, Mission Girls: Aboriginal Women on Catholic Missions in the Kimberley, Western Australia, 1900-1950, University of Western Australia Press, Crawley.

Dashwood, CJ 1902, Pearl-shelling Industry in Port Darwin and Northern Territory, Government Printer, Melbourne.

Edwards, Penny and Shen Yuanfang 2001, 'Something more, towards reconfiguring Australian history', in Lost in the Whitewash: Aboriginal-Asian Encounters in Australia, 1901-2001, Penny Edwards and Shen Yuangang (eds): $1-22$.

Elinghaus, Katherine 2006, Taking Assimilation to Heart: Marriages of White Women an Indigenous Men in the United States and Australia, 1887-1937, University of Nebraska Press, Lincoln. 
ABORIGINAL HISTORY 2011 VOL 35

Faulkner, Samantha with Ali Drummond 2007, Life Belong Ali Drummond: A Life in the Torres Strait, Aboriginal Studies Press, Canberra.

Ganter, Regina 1994, The Pearl-Shellers of Torres Strait, Melbourne University Press, Carlton.

-, with contributions from Julia Martínez and Gary Lee 2006, Mixed Relations, Asian-Aboriginal Contact in North Australia, University of Western Australia Press, Crawley.

- and Ros Kidd 1993, 'The powers of protectors: conflicts surrounding Queensland's 1897 Aboriginal legislation', Australian Historical Studies 25: 536-554.

Macknight, Campbell 1976, The Voyage to Marege: Macassan Trepangers in Northern Australia, Melbourne University Press, Carlton.

Markus, Andrew 1994, Australian Race Relations, 1788-1993, Allen \& Unwin, St Leonards.

Martínez, Julia 1999, 'The "Malay" community in pre-war Darwin', Asians in Australian History: Queensland Review 6(2): 45-58.

- 2005, 'The end of indenture? Asian workers in the Australian pearling industry, 1901-1972', International Labor and Working-Class History 67: 125-147.

- 2006, 'Ethnic policy and practice in Darwin', in Mixed Relations, Regina Ganter with contributions by Julia Martínez and Gary Lee, University of Western Australia Press, Crawley: 122-145.

McGrath, Ann 2003, 'The golden thread of kinship: mixed marriages between Asian and Aboriginal women during Australia's Federation Era', in Lost in the Whitewash: Aboriginal-Asian Encounters in Australia, 1901-2001, Penny Edwards and Shen Yuangang (eds): 37-58.

Osborne, Elizabeth 1997, Torres Strait Islander Women and the Pacific War, Aboriginal Studies Press, Canberra.

Shnukal, Anna and Guy Ramsay 2004, 'Tidal flows: an overview of Torres Strait Islander-Asian contact', in Navigating Boundaries: The Asian Diaspora in Torres Strait, Anna Shnukal, Guy Ramsay and Yuriko Nagata (eds), Pandanus Books, Canberra: 33-52.

Stephenson, Peta 2009, 'Keeping it in the family: partnerships between Indigenous and Muslim communities in Australia', Aboriginal History 33: 97-116. 
Tamura, Keiko 2001, 'The entry of Japanese war brides into Australia', in Relationships: Japan and Australia, 1870s-1950s, Paul Jones and Vera Mackie (eds), The History Department, University of Melbourne, Melbourne: 241264.

Tavan, Gwenda 2005, The Long, Slow Death of White Australia, Scribe Publications, Carlton.

Yu, Sarah 1999, 'Broome Creole: Aboriginal and Asian partnerships along the Kimberley coast', Asians in Australian History: Queensland Review 6(2): 59-73. 